\title{
DYSTRYBUCJA MARMURU PROKONNESKIEGO U WYBRZEŻY ZACHODNIEJ I PÓŁNOCNEJ CZĘŚCI MORZA CZARNEGO W OKRESIE RZYMSKIM WCZESNOBIZANTYJSKIM
}

\author{
(autoreferat wygloszony w trakcie obrony doktorskiej
}

w dniu 11 lutego 2003 r.)

Celem pracy było przedstawienie zagadnienia dystrybucji marmuru pochodzącego z wyspy Marmara (antyczny Proconnesos) w strefie nadczarnomorskiej. Praca jest próbą prześledzenia na podstawie dostępnych źródeł archeologicznych, pisanych i ikonograficznych drogi, jaką pokonywał ten surowiec w postaci detalu i elementów architektonicznych od kamieniołomu do miejsca przeznaczenia, gdzie znajdował swoje zastosowanie. Jest także próbą ustalenia roli i znaczenia tego surowca $w$ okresie rzymskim i wczesnobizantyjskim oraz okoliczności zewnętrznych, wpływających na rozmiary jego dystrybucji. Obok realizacji tematu zasadniczego przeprowadzilam równolegle studia nad technikami wydobycia i obróbki marmuru.

Zabytki wykonane z marmuru prokonneskiego, stanowiące podstawę źródłową niniejszej pracy, pochodzą z wybrzeży zachodnich i północnych części Morza Czarnego oraz znad dolnego biegu Dunaju. Są to głównie sarkofagi, elementy architektoniczne i rzeźby. Stwierdzić trzeba, że studia nad prezentowanym tematem napotykają na pewne trudności. Stan zachowania zabytków, a także niepełne informacje na ich temat w literaturze przedmiotu, nie pozwalają na uściślenie wszystkich danych, koniecznych do całkowitej analizy. Najczęściej brak wiadomości dotyczących liczby dokładnych wymiarów i kontekstu znalezienia omawianych zabytków marmurowych.

Ostatecznie w katalogu znalazło się 31 miast, w których zarejestrowano obecność zabytków wykonanych z marmuru prokonneskiego. Nazwy miast umieszczone zostały w układzie alfabetycznym, według nazw antycznych (współczesna nazwa w nawiasie).

Jako ramy chronologiczne pracy przyjęłam okres rzymski i wczesnobizantyjski. Dolną granicę okresu uwzględnionego $\mathrm{w}$ pracy wyznaczają nieliczne znaleziska detali architektonicznych wykonanych $\mathrm{z}$ marmuru prokonneskiego, $\mathrm{z}$ terenów zachodniego Nadczarnomorza i dolnodunajskich, związane $z$ inwestycjami budowlanymi przeprowadzanymi po najazdach barbarzyńskich i urbanizacją tych terenów realizowaną za rządów Trajana (98-117 r. n.e.).

Górną granicę dystrybucji marmuru prokonneskiego na te tereny wyznacza, trwający ponad sto lat, okres urbanizacji związany z zakładaniem i budową bazylik wczesnochrześcijańskich. Okres ten został zapoczątkowany przez Konstantyna Wielkiego (306-337 r. 
n.e.) i kontynuowany był później głównie przez Anastazjusza I (491-518 r. n.e.) oraz Justyniana Wielkiego (527-565 r. n.e.). Cały materiał zabytkowy pochodzi zasadniczo z okresu między początkiem II w. a końcem VI w. n.e.

Wyspa Marmara (antyczne Proconnesos) jest największą z grupy wysp znajdujących się na morzu Marmara. Obecnie nazwa wyspy brzmi Marmara Adasi, wyspa wchodzi w skład terytorium Turcji. Jej górzysta powierzchnia zajmuje obszar $75 \mathrm{~km}^{2}$. Długość wyspy wynosi $18 \mathrm{~km}$ ze wschodu na zachód, a szerokość $10 \mathrm{~km}$ z północy na południe. Nazwa morza, a także wyspy, pochodzi od greckiego „marmaros”, czyli marmuru. Grecy nazywali to morze „Propontis”, czyli przedsionek Morza Czarnego (ryc. 1).

Ze źródeł pisanych dowiadujemy się, że wyspa została skolonizowana przez mieszkańców Miletu w połowie VIII w. p.n.e., a następnie podobna kolonizacja wyszła z Cyzico, które było wówczas największym miastem w tej okolicy. O wydobywaniu marmuru na wyspie w I w. p.n.e. informują nas Strabon, Pliniusz, a także Witruwiusz, opisujący wykorzystanie marmuru prokonneskiego do budowy mauzoleum w Halikarnasie w IV w. p.n.e. Inne źródła pisane dotyczące wyspy Marmara to przede wszystkim relacje podróżników, takich jak: Cristoforo Buondelmonti, Reverendo Covela i Texier.

Marmury budują północną część wyspy, część środkową tworzą gnejsy, na południu zaś występuja łupki muskowitowe (ryc. 2).

Marmury z wyspy Marmara sa barwy białej, miejscami szarej, poprzecinane ciemnymi „warstewkami” (paskami). Na podstawie badań mikroskopowych wyróżnia się dwa rodzaje marmurów $\mathrm{z}$ tego rejonu: średnioziarniste marmury kalcytowe oraz drobnoziarniste marmury kalcytowo-dolomityczne $z$ muskowitem. Ciemne paski tworzą minerały

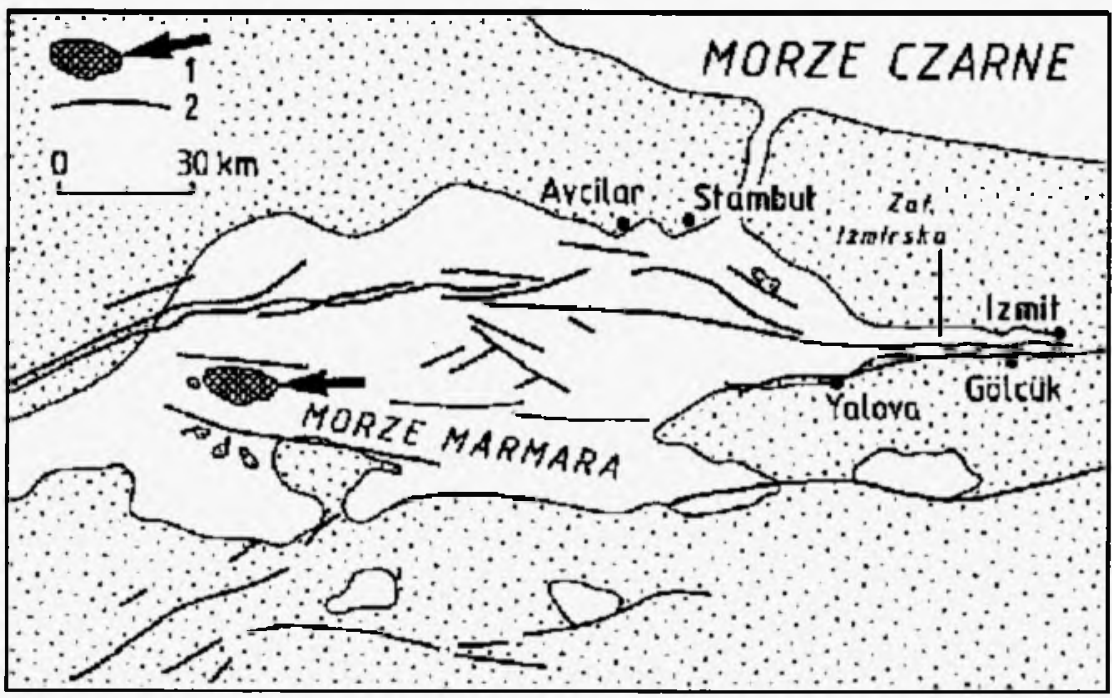

Ryc. 1. Położenie geograficzne i tektoniczne wyspy Marmara: 1- wyspa Marmara i starożytne Proconnesos, 2 - linie uskoków 


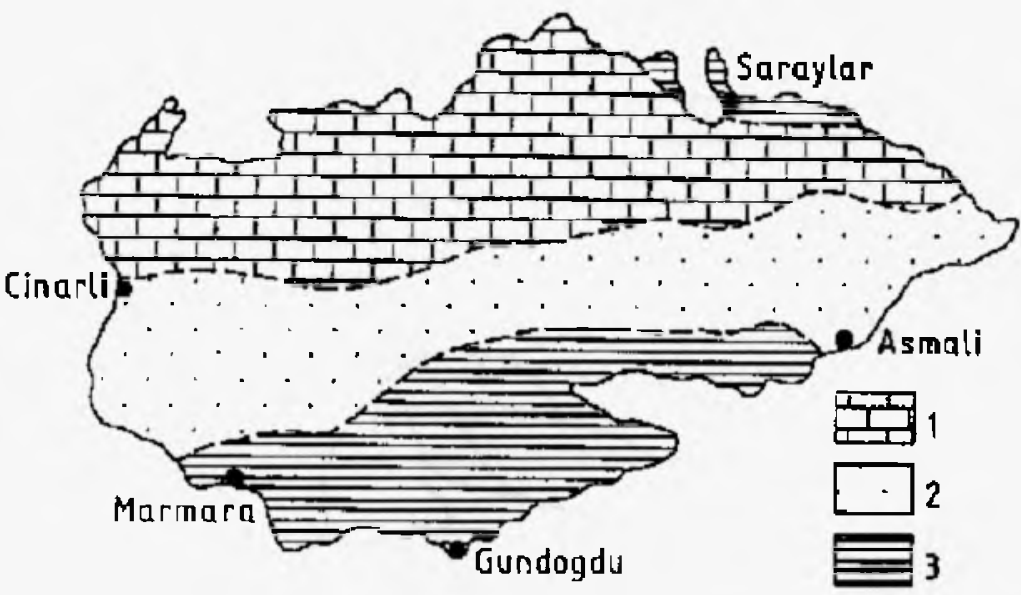

Ryc. 2. Budowa geologiczna wyspy Marmara (wg Mona, Pensabene 1977): 1 - marmury, 2 - lupki, 3 - gnejsy

mikroskopowo nieprzeźroczyste. Marmury te cechuje podatność na polerowanie, szlifowanie, wygładzanie.

Analiza geologiczna marmuru prokonneskiego była możliwa dzięki przeprowadzeniu badań petrograficznych i izotopowych przez prof. J. Skoczylasa i zespół. Do badań petrograficznych dostarczyliśmy 6 próbek z kamieniołomów i lapidarium w Saraylar. Po dokonaniu opisu makroskopowego, z jednej części próbek wykonano płytki cienkie do badań mikroskopowych w świetle przewodzącym, z drugiej części, po sproszkowaniu próbek, przeprowadzone zostały analizy rentgenograficzne metodą DSH. Ponadto w 5 próbkach oznaczono zawartość 12 pierwiastków. Do badań izotopowych dostarczyliśmy 20 próbek. Zostały one poddane analizom izotopowym, wyrażajacym stosunek izotopu ${ }^{18} \mathrm{O}$ do ${ }^{13} \mathrm{C}$. Wyniki analiz zostały naniesione, dla porównania, na wykresy proponowane przez K. Matthewsa i N. Hertza. Wykresy te przedstawiaja zasięgi pól izotopowych dla większości greckich kamieniołomów.

Leżąca w północnej części wyspy współczesna osada Saraylar jest miejscem, wokół którego obecnie funkcjonują współczesne kamieniołomy (ryc. 3).

W 1971 r. w zachodniej części Saraylar rozpoczęto budowę dwóch falochronów, wynikiem czego było odkrycie nekropolii znajdującej się w jednej z dolin i rozpoczęcie badań archeologicznych na terenie kamieniołomów. Podczas tych badań nie odkryto żadnych zabytków z okresu greckiego, natomiast zarejestrowano liczne obiekty z okresu rzymskiego i bizantyjskiego.

Pierwsze znane zabytki wykonane w marmurze to tradycyjna rzeźba $\mathrm{z}$ terenów wysp greckich, która pojawiła się w późnym okresie środkowego neolitu-ok. 5000 p.n.e. i okresie późnego neolitu - ok. 4500 p.n.e. Rzeźbiono wówczas na Krecie i Cykladach oraz w Azji 


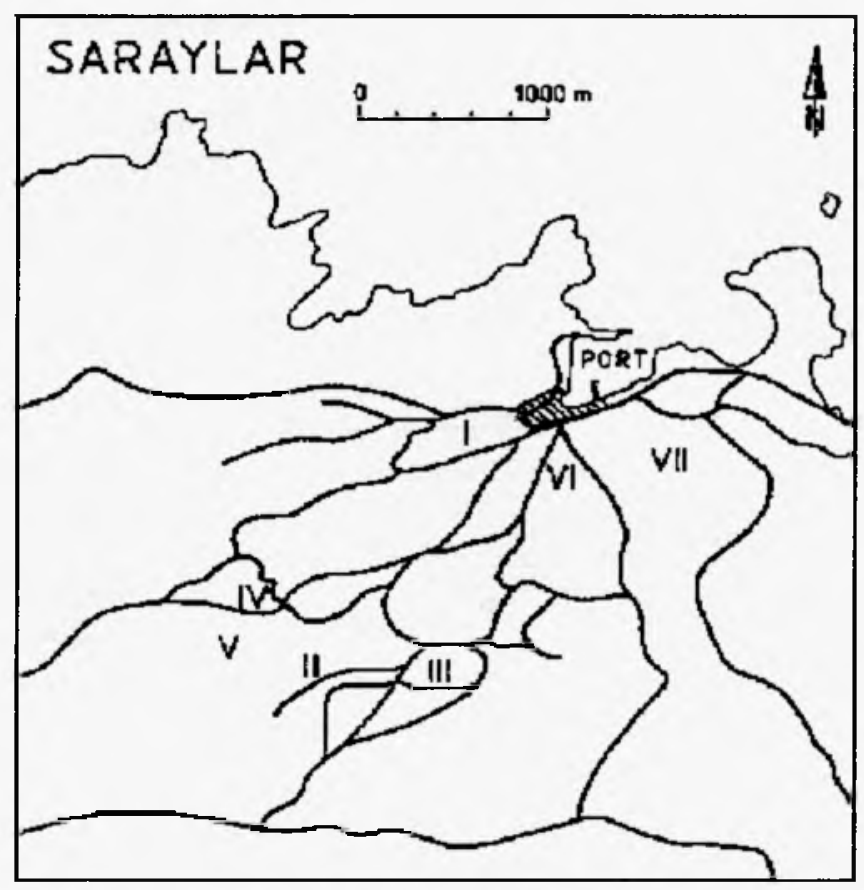

Ryc. 3. Usytuowanie lapidariów w okolicy Saraylar (wg A sgari 1978)

Mniejszej male, antropomorficzne figurki z marmuru. W epoce brąu (3000 p.n.e.) kontynuowano rzeźbę w kamieniu na Cykladach. Do wyrobu niewielkich figur i naczyń używano otoczaków zbieranych z plaż, częściowo uformowanych na skutek działania morza.

Planowa eksploatacja złóż kamiennych zaczęła się dopiero na terenie Egiptu za panowania III dynastii (ok. 2686-2613 r. p.n.e.), kiedy wprowadzono rzeźbiarstwo monumentalne.

Najstarsze egipskie kamieniołomy były miejscem wydobywania miękkich kamieni, takich jak piaskowiec czy wapień. Wprowadzono wówczas technikę wycinania bloków ze skały poprzez wykuwanie dookolnych rowków. Narzędzia używane do tego celu pozostawialy widoczne ślady na stromych ścianach kamieniołomów. Na ich podstawie ustalono przejście od słabych, małych, miedzianych oskardów do dłuższych, wykonanych z brązu, pojawiających się w okresie Nowego Państwa (ok. 1500 r. p.n.e.), które następnie, za panowania XIX dynastii, przekształciły się w jeszcze większe i mocniejsze. Ostatecznie między VIII a VI w. p.n.e. wprowadzone zostały oskardy żelazne, czego ślady zarejestrowano na większości ścian ptolemejskich i rzymskich kopalń. Ustalono też, że aż do okresu ptolemejskiego kilofy nie były powszechnie używane jako narzędzia kopalniane do wydobywania miękkich kamieni.

Zarówno w Egipcie, jak i w Grecji rozmaite techniki wydobywcze były związane z określonymi problemami natury technicznej. Uważa się, że egipskie techniki cięcia 
rowków wokół bloków były początkowo autonomicznym i najbardziej oczywistym sposobem wydobycia kamienia, który później szybko opanował wschodni basen Morza Śródziemnego i Morza Egejskiego.

Od schyłku VI w. p.n.e. większość głównych kamieniołomów greckiego świata była już w pełni czynna. Greccy kamieniarze pozyskiwali bloki poprzez wycinanie w skale macierzystej z trzech, a nawet z czterech stron rowków kilofem, po czym odspajali je od podloża za pomocą klinów.

Po zaanektowaniu Egiptu przez Augusta w 30 r. p.n.e. większość głównych kopalń stała się własnością cesarstwa. Początkowo pracowały one głównie na rzecz cesarskich projektów budowlanych, stopniowo jednak, szczególnie po pełnej reorganizacji, otworzyły się na potrzeby miast i osób prywatnych. W rezultacie doszło do masowej produkcji elementów architektonicznych, częściowo standaryzowanych, takich jak kolumny, kapitele i bazy.

Wszystko to wyraźnie pokazuje, że w czasach starożytnych poszczególne techniki rozłupywania kamieni istniały obok siebie. Większość z nich stosowano już od VI w. p.n.e. Kiedy i w jaki sposób były one wykorzystywane, określają głównie umiejętności i doświadczenie kamieniarzy w kamieniołomach, których wiedza na ten temat była niekiedy ważniejsza niż narzędzia, jakich używali.

Techniki eksploatacji kamienia nie ulegały dużym zmianom od czasów starożytnych aż do początku XX w. Do niedawna jeszcze stosowano wydobycie polegające na wykorzystaniu naturalnych pęknięć w skale, czy wydobycie przez szok termiczny, wywoływany zmianami temperatury, oraz wykuwanie bloku ze skaly za pomocą dłut, młotów i zakładanie klinów.

Przenosząc na starożytność doświadczenia nowożytnych górników i kamieniarzy badacze problemu ustalili wykaz zagadnień dotyczących techniki górnictwa kamiennego. Są to: wybór miejsca pod kamieniołom, sposób dotarcia do złoża produkcyjnego, roboty początkowe, rozwój pionowy i poziomy kamieniołomu, sposoby wyłamywania kamienia i używane do tego narzędzia, uwzględnienie i wykorzystanie do celów wydobywczych naturalnych właściwości skały (twardość, uwarstwienie i jego kierunek, spękanie, łupliwość i in.) oraz gospodarkę wodą.

Czynnościami związanymi z eksploatacją złóż kamiennych są: prace poszukiwawcze (wstępne i odkrywkowe), odwodnienie kamieniolomu, wydobycie materiahu kamiennego, ręczna obróbka oraz transport kamienia. Z czynnościami tymi związany jest charakterystyczny zestaw narzędzi, jak młotek, pobijak oraz dłuto wykonane z żelaza lub brązu.

Towary sprowadzane $z$ Italii przez Grecję na tereny nadczarnomorskie dostarczane były głównie drogą morską za pośrednictwem greckich miast położonych przy wybrzeżu Morza Czarnego. Opanowanie obszaru dolnodunajskiego przez Rzym nie spowodowało istotnych zmian w wielowiekowym systemie relacji ekonomicznych. Dlatego też marmur, który sprowadzano z rejonów Morza Egejskiego i morza Marmara na tereny nadczarnomorskie, dostarczany był głównie do miast portowych. Biorąc jednak pod uwagę specylikę, historię i związki ludnościowe, uznalam, że nie mogę ograniczyć się jedynie do strefy nadmorskiej. Tereny te, poza pólnocno-wschodnim wybrzeżem Morza 
Czarnego, były ściśle związane z prowincjami rzymskimi: Mezją Dolna, Tracją i strefą dolnego Dunaju. Uwzględniała je polityka militarna Cesarstwa, co znalazło swoje odbicie w dyslokacji wojsk, organizacji osadnictwa, a także - co się z tym wiąże - organizacji zaopatrzenia. Utworzenie po ciężkich zmaganiach wojennych nowej prowincji, Dacji, a także penetracja gospodarcza oraz militarna terytoriów leżących między Dacja i wybrzeżem Morza Czarnego spowodowały, że całe dorzecze dolnego Dunaju, bez względu na przebieg granic, funkcjonowało jak jeden organizm ekonomiczny.

Marmury z wyspy Marmara w początkowym etapie swej wędrówki były dostarczane do miast Kyzico i Nicomedii, gdzie znajdowały się warsztaty, w których poddawano je częściowej lub całkowitej obróbce. W II w. podstawowym odbiorcą surowców i półfabrykatów marmurowych $\mathrm{z}$ wyspy Marmara była Nicomedia. Najsilniejsze kontakty handlowe w zakresie dystrybucji marmuru utrzymywała Nicomedia z następującymi portami położonymi na zachodnim i północnym wybrzeżu Morza Czarnego: Odessos, Tomi, Histrią, Tyras, Olbią i Chersonezem Taurydzkim

Poziom zużycia marmuru w ciagu III i IV w. n.e. do budowy nowych i renowacji starych budynków, głównie użyteczności publicznej, był niewielki i zależał od lokalnych władz. Dostarczycielem marmuru w dalszym ciągu była Nicomedia, lecz w mniejszym stopniu. Po powstaniu nowej stolicy - Konstantynopola - przeniesiono do niej główne warsztaty kamieniarskie. Liczne ataki barbarzyńców w pierwszej połowie $\mathrm{V}$ w. spowodowały duże zniszczenia w głównych miastach portowych Morza Czarnego. Dopiero pod koniec $\mathrm{V}$ w. nastapil okres odbudowy i rozwoju miast nadczarnomorskich.

Największy eksport detali wykonanych z marmuru prokonneskiego na zachodnie i północne tereny nadczarnomorskie nastapił od drugiej połowy $\mathrm{V}$ w. do końca VI w. w okresie panowania Anastazjusza I (491-518 r.) i Justyniana I Wielkiego (527-565). Detale wykonane z marmuru prokonneskiego były wówczas eksportowane do miast nadmorskich oraz znajdujących się nad dolnym biegiem Dunaju, takich jak: Anchialus, Odessos, Callatis, Histria, Chersonez Taurydzki, Bosporus-Theodosia, Dinogetia, Ibida, Noviodunum, Novae, Marcianopolis, Pliska, Preslav i Šumen.

Kartografia występowania detali $\mathrm{z}$ marmuru prokonneskiego $\mathrm{w}$ drugiej połowie V i VI w. wykazuje wyraźnie ich zagęszczenie w strefie zachodniego wybrzeża, gdzie pojawiają się one w miastach portowych. Znacznie wzrasta też ilość znalezisk w strefie lądowej, szczególnie w pasie do $50 \mathrm{~km}$ od wybrzeża. Analiza wskazuje, że transport do miejscowości śródlądowych odbywał się w większości szlakami rzecznymi, a docelowo, na krótkim odcinku, lądowymi. Funkcjonowal oczywiście także szlak dunajski.

W starożytnym Rzymie transport odbywał się głównie drogami morskimi, byla to bowiem najtańsza i najwydajniejsza możliwość przewozu towarów. Do innych sposobów należały przewozy rzeczne, niewiele droższe od morskich, oraz lądowe.

Do portów morskich i rzecznych zawijały statki różnego typu. Różnice konstrukcyjne wynikały z funkcji statków. Inaczej budowano transportowe liburae, należące do typu statków naves oneraria, a inaczej cladiuta, hippagi, które służyły do transportu koni. Jeszcze inną konstrukcję miały navis lapidaria i navis magna, transportujące materiały tak ciężkie jak marmury. 
Z trasami morskimi ściśle wiążą się szlaki żeglugi rzecznej. Często korzystano na nich z tych samych statków co na morzu i przedłużano szlaki morskie na rzeki prowadzące do portów w głębi lądu. Żegluga rzeczna rozwijała się najintensy wniej w okresie schylku Republiki i w czasach Cesarstwa. Rzekami pływały najróżniejsze statki od dłubanek i tratw po statki morskie. Operowały one u ujścia wielkich rzek, a nawet kilkadziesiąt mil w głąb lądu, zależnie od głębokości toru wodnego.

Drogi lądowe na prowincji budowano głównie z powodów wojskowych, ale oczywiście wykorzystywano je także do przewozu towarów nie związanych z wojskiem. Jednak ze względu na ciężar i objętość marmurów unikano tego typu transportu, przewożąc je głównie drogą wodną. W sytuacji gdy taki transport był konieczny, stosowano wozy czterokołowe o solidnej konstrukcji i wąsko rozstawionych kołach nazywane sarracum.

Gromadzenie wyrobów marmurowych w kopalniach i wydzielonych magazynach zostało zapoczątkowane przez dynastię julijsko-klaudyjską, kiedy upaństwowiono najważniejsze kamieniolomy na lądzie greckim i wyspach egejskich oraz w Azji Mniejszej i Egipcie. Duże kamieniołomy znajdujące się w obrębie Cesarstwa zostaly zreorganizowane i nastawione na produkcję masową. Początkowo, w ciagu drugiej połowy I w., głównym odbiorcą ich wyrobów był Rzym. W krótkim jednak czasie produkcja przekroczyła zapotrzebowanie Rzymu i okolicznych miast powodując powstanie nadwyżek, a co się z tym wiązało - powstanie magazynów. Z początkiem II w. całe imperium stało się rynkiem zbytu dla wyrobów kamieniarskich. Marmury, granity i inne kamienie docierały do najdalszych zakątków Cesarstwa, na przykład: granity z Egiptu były znajdowane od Lyonu po Palmyrę, a marmur giallo antico od Numidii, przez Brytanię po Morze Czarne. Prywatne lub będące w posiadaniu lokalnej wspólnoty kamieniołomy pracowały jako oddzielne zespoły zaopatrujące lokalne regiony, pozostawiając handel zamorski systemowi państwowemu. Imperium było właścicielem kamieniołomów produkujących najlepsze białe i kolorowe marmury, ustanawiało ceny oraz administrowało całym złożonym systemem produkcji, transportu, magazynowania i dystrybucji.

Poziom zużycia marmuru zależał od decyzji lokalnych władz miast rzymskich i prowincjonalnych oraz od bogatych obywateli i imperatora. W ciagu III w. n.e. wzrost inflacji, podniesienie podatków i liczne wojny doprowadziły do zaniku warstwy średniej i obniżenia poziomu życia. Ekonomiczne ograniczenia spowodowały także wstrzymanie budowy wielkich budynków użyteczności publicznej oraz napraw i renowacji innych. W prowincjach kwestie te zostały pozostawione w rękach lokalnych patrycjuszy. Handel marmurem ekskluzywnym podupadał w dobie katastrof socjalno-ekonomicznych. Prywatne zapotrzebowanie na sarkofagi marmurowe, które były symbolem pewnego statusu, najlepiej obrazowało wykorzystanie marmuru oraz upadek części warsztatów w drugiej połowie III w. n.e.

Niewielkie zużycie kamienia do nowych konstrukcji w okresie panowania Konstantyna I (306-337) powinno doprowadzić do upadku przemysłu marmurowego we wczesnym IV w. Jednak stało się inaczej, a to dzięki powstaniu nowej stolicy i związanym z wprowadzaniem chrześcijaństwa szeroko zakrojonym planom budowy bazylik. 
W V i VI w. cały budowlany i dekoracyjny marmur wysyłany na północne wybrzeże Adriatyku, i na tereny nadczaromorskie pochodził z Prokonnezu. Największy eksport na tereny nadczarnomorskie detali wykonanych z marmuru prokonneskiego wystapił między drugą połową V w. i pierwszą połową VI w. Detale były eksportowane głównie do miejscowości nadmorskich i znajdujących się nad dolnym Dunajem. Przykładem są takie miasta, jak: Histria, Dinogetia, Callatis, Novae, Marcianopolis, Odessos, Mesembria i Chersonez Taurydzki. Jest rzeczą interesująca, że podstawowe regulacje prawne dotyczące wydobycia i obrotu marmurem pochodzą z IV w., a więc okresu, w którym notujemy relatywnie słabsze zainteresowanie tym surowcem. Były one zawarte w dioklecjańskim Edykcie o maksymalnych cenach z $301 \mathrm{r}$. Została tam zamieszczona lista dwudziestu istniejących w handlu marmurów. W Kodeksie Teodozjusza zostały określone prawa dotyczące wydobycia marmuru w rejonie Konstantynopola. Sa to prawa $z$ lat 320,363 i 376 popierające prywatne, indywidualne zakładanie nowych kamieniołomów oraz kontynuowanie wydobycia w starych. Efektem tych praw był wzrost sprzedaży marmuru w prowincjach, obniżanie cen i częstsze odnawianie starych budynków użyteczności publicznej.

Opracowując niniejszy temat starałam się dotrzeć do możliwie jak największej liczby źródeł dotyczących wyrobów wykonanych $\mathrm{z}$ marmuru prokonneskiego. Mam jednak świadomość, iż nie jest to pełen zbiór, ponieważ nie wszystkie wyroby z tego marmuru zostały opublikowane. $Z$ tego względu wiele istotnych pytań musiało pozostać bez odpowiedzi, a proponowane wyjaśnienia nie mogły zostać w pełni udokumentowane. Niemniej wydaje mi się, że zgromadzone dane odzwierciedlają znaczenie surowca prokonneskiego, ukazują podstawowe reguly jego pozyskiwania, obróbki, rozprowadzania i pozwalają uchwycić zmiany, jakie w tym zakresie zachodzily na terenach zachodniego i północnego Nadczarnomorza w określonej sytuacji polityczno-gospodarczej.

\section{Katarzyna Grala}

Instytut Prahistorii, Uniwersytet im. Adama Mickiewicza ul. Św. Marcin 78, 61-809 Poznań, Poland 